\title{
Analisis Struktur Sistem Aplikasi Pengolahan Data Layanan Pasien Rekam Mendik
}

\author{
Sudarmaji 1)* \\ ${ }^{1 *}$ Ilmu Komputer, Fakultas Ilmu Komputer, Universitas Muhammadiyah Metro \\ Jl. Ki. Hajar Dewantara No. 116 Iringmulyo Kota Metro Lampung \\ *Corresponding Author's E-Mail: majidarma5022@gmail.com ${ }^{1)}$
}

\begin{abstract}
ABSTRAK
Pengolahan data layanan kesehatan klinik hadi wijaya masih dilakukan secara manual, dan belum selaras dengan tujuan Peraturan Menteri Kesehatan Republik Indonesia No. 46 Tahun 2017. Hal ini menyebabkan kegiatan operasional pelayanan membutuhkan waktu yang lama dan apabila terjadinya suatu kesalahan dalam melakukan penginputan data petugas akan mengalami kesulitan dalam memperbaiki data tersebut. Selain itu, proses pencarian data rekam medik pasien juga membutuhkan waktu yang lama dikarenakan proses penyimpanannya yang masih menggunakan buku besar. Penelitian ini bertujuan untuk meningkatkan proses pengolahan data rekam medik dengan memanfaatkan teknologi informasi. Penelitian ini menggunakan metode analisis terstruktur berorientasi aliran data. Pengembangan aplikasi ini menghasilkan aplikasi yang telah sesuai dengan kebutuhan Klinik Hadi Wijaya Kota Metro dalam proses pengolahan data rekam medik.
\end{abstract}

Kata Kunci-Analisis terstruktur, Aplikasi Rekam Medis, Teknologi Informasi

\section{Pendahuluan}

Terobosan teknologi informasi dan komunikasi (TIK) yang telah merambah di segala segi kehidupan, sehingga penerapan TIK di bidang kesehatan telah menjadi tuntutan organisasi/institusi kesehatan tidak hanya di sektor pemerintah tetapi juga di sektor swasta dalam menjalankan operasional pelayanannya. Seperti yang tertuang pada Peraturan Menteri Kesehatan Republik Indonesia No.46 Tahun 2017, pemanfaatan TIK dalam bidang kesehatan berperan untuk meningkatkan kualitas, aksesibilitas, dan kesinambungan upaya kesehatan serta kecepatan proses kerja pada pelayanan kesehatan. Selain itu pemanfaatan TIK juga berperan dalam mengoptimalkan aliran data sehingga meningkatkan ketersediaan data dan informasi kesehatan yang berkualitas [1].

Klinik Hadi Wijaya Kota Metro merupakan salah satu klinik kesehatan swasta yang melayani rawat jalan, rawat inap, dan pelayanan 24 jam. Pengolahan data layanan kesehatan klinik hadi wijaya masih dilakukan secara manual, dan belum selaras dengan tujuan Peraturan Menteri Kesehatan Republik Indonesia No. 46 Tahun 2017 [1]. Hal ini menyebabkan kegiatan operasional pelayanan membutuhkan waktu yang lama dan apabila terjadinya suatu kesalahan dalam melakukan penginputan data petugas akan mengalami kesulitan dalam memperbaiki data tersebut. Selain itu, proses pencarian data rekam medik pasien juga membutuhkan waktu yang lama dikarenakan proses penyimpanannya yang masih menggunakan buku besar.

Sesuai dengan Peraturan Menteri Kesehatan Republik Indonesia No. 269 Tahun 2008, bahwa berkas yang berisi catatan dan dokumen tentang identitas, pemeriksaan, pengobatan, tindakan dan pelayanan lain kepada pasien pada sarana layanan kesehatan merupakan rekam medik yang harus dibuat secara tertulis, lengkap, dan jelas atau secara elektronik [2]. Penelitian ini akan memanfaatkan teknologi informasi dalam proses pengolahan data rekam medik yang ada pada Klinik Hadi Wijaya Kota Metro. Perancangan aplikasi pengolahan data rekam medik akan berbasis delphi 7.0.

Penelitian sebelumnya terkait pengolahan data rekam medik pernah dilakukan oleh Dzurriyatul Iflahah., dkk (2018) tentang analisis dan perancangan sistem informasi rekam medis poli gigi [3], Novita Nuraini (2015) tentang analisis sistem penyelenggaraan rekam medis di Instalasi rekam medis Rs. X di Tangerang [4], dan penelitianpenelitian lain yang sudah banyak dilakukan di berbagai layanan kesehatan di Indonesia. Penelitian ini bertujuan untuk merancang aplikasi pengolahan data rekam medik di Klinik Hadi Wijaya Kota Metro sampai dengan proses laporan data rekam mediknya. 


\section{Jurnal Ilmu Komputer \& Informatika JIKI}

Perancangan aplikasi pengolahan data rekam medik pada penelitian ini akan dirancang menggunakan metode analisis terstruktur berorientasi aliran data (Data Flow Oriented atau Functions). Metode analisis yang dikembangkan oleh Tom DeMarco, Chris Gave, Trish Sarson, dan Edward Yourdon ini menggunakan perangkat pemodelan seperti Data Flow Diagram, Entity-Relationship Diagram, dan State Transition Diagram [5]. Penerapan metode ini diharapkan dapat mengidentifikasi secara tepat fungsi-fungsi atau proses-proses apa saja yang akan ada di dalam sistem, data apa saja yang akan menjadi masukkan, dimana data akan disimpan, transformasi apa yang akan dilakukan terhadap data, dan bagaimana hasil transformasinya.

Penelitian ini terdiri dari lima bab. Bab pertama adalah pendahuluan, yang menjelaskan masalah dan tujuan penelitian. Kedua adalah tinjauan pustaka terkait teori-teori terkait perancangan aplikasi pengolahan data rekam medik. Bab ketiga menyajikan metodologi yang digunakan pada penelitian ini. Bab keempat akan menampilkan hasil analisis dan pengembangan aplikasi serta bab terakhir adalah kesimpulan.

\section{TINJAUAN PUSTAKA}

\section{A. Rekam Medik}

Berdasarkan Peraturan Menteri Kesehatan Republik Indonesia, baik Nomor No. 749a Tahun 1989 maupun Nomor 269 Tahun 2008, rekam medis diartikan sebagai berkas yang berisikan catatan dan dokumen tentang identitas pasien, pemeriksaan, pengobatan, tindakan dan pelayanan lain yang telah diberikan kepada pasien [2], [6]. Dimana jenis dan isi rekam medik harus dibuat secara tertulis, lengkap dan jelas atau secara elektronik [2].

Sehingga dapat disimpulkan bahwa suatu berkas rekam medis mempunyai arti yang lebih luas daripada hanya sekedar catatan biasa, karena didalam catatan tersebut sudah memuat segala informasi menyangkut seorang pasien yang akan dijadikan dasar untuk menentukan tindakan lebih lanjut kepada pasien. Sedangkan rekam medik elektronik dapat diartikan sebagai salah satu penerapan e-kesehatan di Indonesia yang menangani pengolahan data rekam medik dengan fungsionalitas sistem informasi yang dapat mencakup segala proses rekam medik secara manual.

\section{B. Perancangan Sistem Informasi}

Sistem informasi merupakan kombinasi antara manusia, fasilitas atau alat teknologi, media, prosedur dan pengendalian yang memiliki kemampuan mengumpulkan informasi dari sumber dan memakai beberapa media untuk menampilkan informasi [3], [7]. Sehingga perancangan sistem informasi dapat diartikan sebagai proses penerjemahan analisis sistem informasi yang telah diidentifikasi dari berbagai stakeholder atau pemangku kepentingan menjadi blueprint untuk membangun sebuah perangkat lunak [8].

Perancangan sistem informasi dapat dilakukan dengan menggunakan dengan berbagai metode, salah satunya adalah metode analisis terstruktur berorientasi aliran data (Data Flow Oriented atau Functions). Metode analisis ini yang dikembangkan oleh Tom DeMarco, Chris Gave, Trish Sarson, dan Edward Yourdon ini menggunakan perangkat pemodelan seperti Data Flow Diagram (DFD), Entity-Relationship Diagram (ERD), dan State Transition Diagram [5].

\section{Data Flow Diagram (DFD)}

Data Flow Diagram (DFD) merupakan salah satu alat pembuatan model yang digunakan untuk menggambarkan suatu sistem yang telah ada atau sistem baru yang akan dikembangkan secara logika tanpa mempertimbangkan lingkungan fisik dimana data tersebut disimpan. Tabel 1 menunjukkan simbol-simbol yang digunakan dalam DFD dengan tahapan pembuatan DFD sebagai berikut .

1. Diagram Konteks, adalah digram level tertinggi dari DFD yang menggambarkan hubungan sistem dengan lingkungan lainnya seperti yang digambarkan pada. Perancangan diagram konteks dilakukan dengan cara:

- Menentukan batasan sistemnya

- Menentukan terminator apa saja yang ada dalam sistem

- Menentukan apa yang diterima kemudian diberikan external entity dari atau ke sistem.

- Gambarkan diagram konteks

2. Diagram Level Nol (Overview Diagram), adalah dekomposisi atau penguraian menjadi bentuk lebih sederhana dari diagram, yang dirancang dengan cara:

- Menentukan proses utama yang ada pada sistem

- Menentukan apa yang diberikan atau diterima masing-masing proses ke atau dari sistem kemudian memperhatikan konsep keseimbangan (alur data yang keluar atau masuk dari suatu level harus sama dengan alur data yang masuk atau keluar pada level berikutnya.

- Apabila diperlukan, muncul data store (master) sebagai sumber maupun tujuan alur data.

- Hindari perpotongan arus data

- Beri nomor pada proses utama (nomor tidak menunjukan urutan proses) 
TABLE I. SIMBOL PADA DATA FLOW DIAGRAM (DFD)

\begin{tabular}{|c|c|c|}
\hline No & Simbol & Keterangan \\
\hline 1 & & $\begin{array}{l}\text { Proses (process) } \\
\text { Simbol ini digunakan untuk } \\
\text { menunjukan proses pengolahan } \\
\text { atau transformasi data pada } \\
\text { bagian yang mengubah input } \\
\text { menjadi ouput. }\end{array}$ \\
\hline 2 & & $\begin{array}{l}\text { Kesatuan Luar (External } \\
\text { Entity) } \\
\text { Simbol ini digunakan untuk } \\
\text { menggambarkan asal atau } \\
\text { tujuan data di lingkungan luar } \\
\text { sistem yang dapat berupa orang, } \\
\text { organisasi, atau sistem lain yang } \\
\text { memberikan atau menerima } \\
\text { output dari sistem }\end{array}$ \\
\hline 3 & & $\begin{array}{l}\text { Alir Data (Data Flow) } \\
\text { Simbol ini digunakan untuk } \\
\text { menggambarkan aliran data } \\
\text { yang berjalan }\end{array}$ \\
\hline 4 & & $\begin{array}{l}\text { Simpanan } \text { Data } \\
\text { Storage) } \\
\text { Simpanan (Data Store) } \\
\text { merupakan simpanan dari data } \\
\text { yang dapat berupa suatu file } \\
\text { atau database pada sistem } \\
\text { komputer }\end{array}$ \\
\hline
\end{tabular}

3. Diagram Level Satu, dekomposisi atau penguraian menjadi bentuk sederhana dari diagram level nol yang dirancang dengan cara:

- Tentukan proses yang lebih kecil (subproses) dari proses utama yang ada di level nol.

- Tentukan apa yang diberikan atau diterima masing-masing sub proses ke atau dari sistem dan perhatikan konsep keseimbangan.

- Apabila diperlukan, munculkan data store (transaksi) sebagai sumber maupun tujuan alur data.

- Hindari perpotongan arus data.

- Beri nomor pada masing-masing sub-proses yang menunjukan dekomposisi dari proses sebelumnya

\section{Entity Relationship Diagram (ERD)}

ERD merupakan gambaran yang menghubungkan antara objek satu dengan objek yang lain dalam dunia nyata. Bisa dikatakan bahwa bahan yang akan digunakan untuk membuat ERD adalah dari objek di dunia nyata. Sebagai contoh, jika akan membuat ERD dari sistem akademik suatu perguruan tinggi, maka bahan sebagai objek ERD bisa berupa mahasiswa, dosen, ruang kelas, mata kuliah, dan lain sebagainya. Beberapa struktur data dan hubungan antar data, untuk menggambarkan digunakan beberapa notasi dan simbol seperti pada tabel 2 .

TABLE II. SIMBOL PADA ENTITY RELATIONSHIP DIAGRAM (ERD)

\begin{tabular}{|c|c|}
\hline Notasi & Keterangan \\
\hline & $\begin{array}{c}\text { Entitas, adalah suatu objek yang } \\
\text { dapat diidentifikasi dalam } \\
\text { lingkungan pemakai. }\end{array}$ \\
\hline & $\begin{array}{c}\text { Relasi, menunjukkan adanya } \\
\text { hubungan di antara sejumlah entitas } \\
\text { yang berbeda. }\end{array}$ \\
\hline & $\begin{array}{c}\text { Atribut, berfungsi mendeskripsikan } \\
\text { karakter entitas (atribut yang } \\
\text { berfungsi sebagai key diberi garis } \\
\text { bawah). }\end{array}$ \\
\hline & $\begin{array}{c}\text { Garis, sebagai penghubung antara } \\
\text { relasi dengan entitas, relasi dan } \\
\text { entitas dengan atribut. }\end{array}$ \\
\hline
\end{tabular}

Ada tiga macam relasi menurut derajatnya, yaitu sebagai berikut.

\section{Relasi Satu-ke-satu (One to One)}

Adanya relasi antara himpunan entitas Dosen dengan entitas Jurusan. Himpunan relasinya kita beri nama "mengepalai". Para relasi ini, setiap dosen paling banyak mengepalai satu jurusan (walaupun memang tidak semua dosen yang menjadi satu jurusan). Dan setiap jurusan dikepalai oleh paling banyak satu orang dosen.

\section{Relasi satu-ke-banyak (One to Many)}

Adanya relasi antara himpunan entitas Dosen dengan himpun entitas Kuliah. Himpunan relasinya kita beri nama "Mengajar". Pada relasi ini, setiap dosen dapat mengajar lebih dari satu mata kuliah, sedang setiap mata kuliah diajar hanya oleh paling banyak satu orang dosen.

\section{Relasi banyak-ke-banyak (Many to Many)}

Relasi antara himpunan entitas Mahasiswa dengan himpunan entitas Kuliah. Himpunan relasinya kita beri nama "Mempelajari". Pada relasi ini, setiap mahasiswa dapat mempelajari lebih dari satu mata kuliah. Demikian juga sebaliknya, setiap mata kuliyah dapat dipelajari oleh leih satu orang mahasiswa.

\section{Relasi banyak ke satu (many to one)}

Setiap entitas pada himpunan A berhubungan dengan paling banyak dengan satu entitas pada himpunan entitas B, tetapi tidak sebaliknya, dimana setiap entitas pada himpunan entitas A berhubungan 
dengan paling banyak satu entitas pada himpunan entitas B.

\section{Metodologi Penelitian}

Perancangan aplikasi pengolahan data rekam medik pada penelitian ini dirancang menggunakan metode analisis terstruktur berorientasi aliran data (Data Flow Oriented atau Functions). Metode analisis yang dikembangkan oleh Tom DeMarco, Chris Gave, Trish Sarson, dan Edward Yourdon ini menggunakan perangkat pemodelan seperti Data Flow Diagram, Entity-Relationship Diagram, dan State Transition Diagram [5]. Pengumpulan data sangat dibutuhkan untuk dapat melakukan analisis aliran data. Pproses pengumpulan data penelitian ini menggunakan dua metode pengumpulan data yaitu, Metode Lapangan (studi lapangan) dan Studi Pustaka dengan alur penelitian yang dapat dilihat pada Gambar 1.

\section{E. Metode Lapangan (Studi Lapangan)}

Studi lapangan adalah pengumpulan data yang secara langsung mempelajari yang berkaitan dengan masalah-masalah yang sedang dihadapi. Adapun studi lapangan yang dilakukan adalah sebagai berikut.

1. Pengamatan (observasi), adalah metode pengumpulan data dengan cara mengamati secara langsung pada Klinik Hadi Wijaya sehingga penulis mengetahui secara langsung proses data.

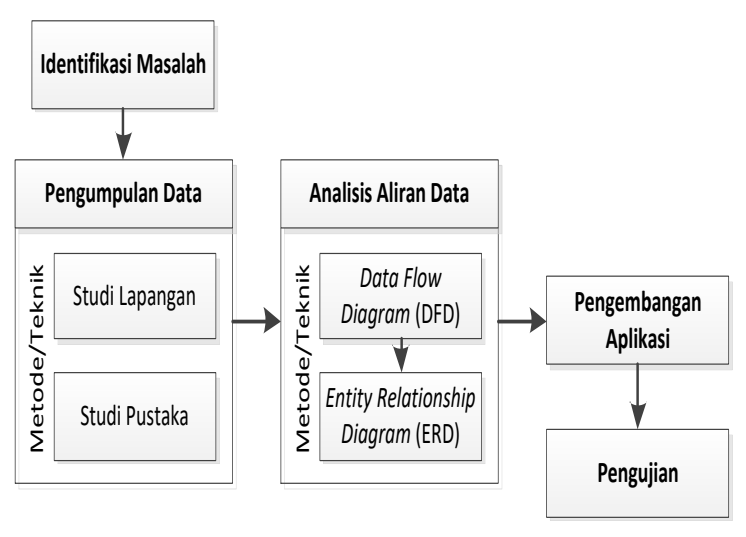

Fig. 1. Alur Penelitian

2. Wawancara( interview ), adalah metode pengumpulan data dengan cara tanya jawab secara langsung dengan petugas rekam medis Klinik Hadi Wijaya Kota Metro.

3. Dokumentasi (documentations), adalah metode dengan mengumpulkan dokumentasi informasi yang ada di klinik hadi wijaya untuk kelengkapan pengumpulan data.

\section{F. Studi Pustaka}

Studi pustaka adalah metode pengumpulan data dengan cara mempelajari literatur-literatur dan bukubuku yang berkaitan dengan masalah yang dihadapi.

\section{Hasil dan PEMbahasan}

\section{G. Identifikasi Masalah}

Dalam melakukan penelitian pada Klinik Hadi Wijaya Kota Metro, penulis menemukan adanya kekurangan pada pengolahan data rekam medis. Proses pengolahan rekam medis tergolong rumit karena penginputan data nomor rekam medis, nama pasien dan diagnosa menggunakan buku besar dan blanko. Blanko yang sudah diisi di masukan dan disusun ke dalam rak arsip. Lamanya proses pencarian dokumen rekam medis pasien yang sudah terdaftar sebelumnya di rak arsip tanpa mengetahui posisi pasti dokumen rekam medis tersebut dikarenakan banyak penomoran arsip yang sama sehingga memerlukan waktu, seringnya ditemui kosongnya dokumen didalam rak arsip akibat terselip atau hilang sehingga menyulitkan petugas karena harus membuat ulang rekam medis baru, lambatnya pembuatan laporan rekam medis yang akan diserahkan kepada kepala klinik.

\section{H. Pengumpulan Data}

Data yang digunakan untuk penelitian ini adalah data primer dan data sekunder. Data primer merupakan data yang diperoleh langsung dari pihak yang diperlukan datanya yaitu Klinik Hadi Wijaya Kota Metro. Sedangkan data sekunder merupakan data yang sudah tercatat dalam buku atau pun suatu laporan. Proses pengumpulan data dilakukan dengan berbagai metode, yaitu studi lapangan (wawancara, observasi, dan dokumentasi) serta studi pustaka.

\section{Studi Lapangan}

Data primer diperoleh dengan menggunakan metode studi lapangan, yaitu wawancara dan observasi. Wawancara dilakukan dengan pihak yang berwenang dan memiliki hubungan langsung dengan proses pengolahan data rekam medik secara manual pada Klinik Hadi Wijaya Kota Metro. Metode ini dilakukan untuk menggali requierement apa yang dibutuhkan dalam pengembangan aplikasi pengelolaan data rekam medik untuk Klinik Hadi Wijaya Kota Metro. Selain wawancara, proses pengidentifikasian requirement dilakukan dengan metode observasi, dimana dilakukan pengamatan langsung terkait kegiatan operasional pengelolaan data rekam medik. Studi lapangan yang lain dilakukan dengan dokumentasi. Proses ini dilakukan untuk memperoleh data sekunder, yaitu data laporanlaporan terkait proses pengelolaan data rekam medik yang ada di Klinik Hadi Wijaya Kota Metro.

2. Studi Pustaka 


\section{Jurnal Ilmu Komputer \& Informatika MKI}

Vol. 1, No. 1, Juli 2020

29

Studi pustaka dilakukan mengumpulkan literature-literatur dan buku-buku yang berkaitan dengan pengembangan aplikasi pengelolaan data rekam medik di bidang kesehatan. Data-data yang telah diperoleh selanjutnya dipelajari guna memperkuat teori-teori yang berkaitan dengan penelitian ini.

\section{Analisis Aliran Data}

Data-data yang telah diperoleh kemudian dibangun aliran sistem yang diusulkan seperti yang ditunjukkan pada Gambar 2. Pasien mendaftar ke bagian petugas rekam medis menyerah kartu identitas pasien atau kartu pasien yang sudah pernah mendaftar. Kemudian petugas rekam medis membuat kan pasien status rekam medis. Status rekam medis diserahkan kan ke badan pemeriksa, dokter, pasien diperiksa lalu hasil pemeriksaan telah di ketahui oleh pasien dan dokter mengisi hasil pemeriksaan pada status rekam medis. Hasil rekam medis yang telah diisi dokter diserahkan ke petugas rekam medis. Kemudian petugas RM menginputkan data rekam medis kedalam Database, melalui aplikasi pengolahan data Rekam Medis pasien. Petugas Rekam medis membuat laporan rekam medis pasien perbulan yag akan diserahkan kepada kepala klinik.

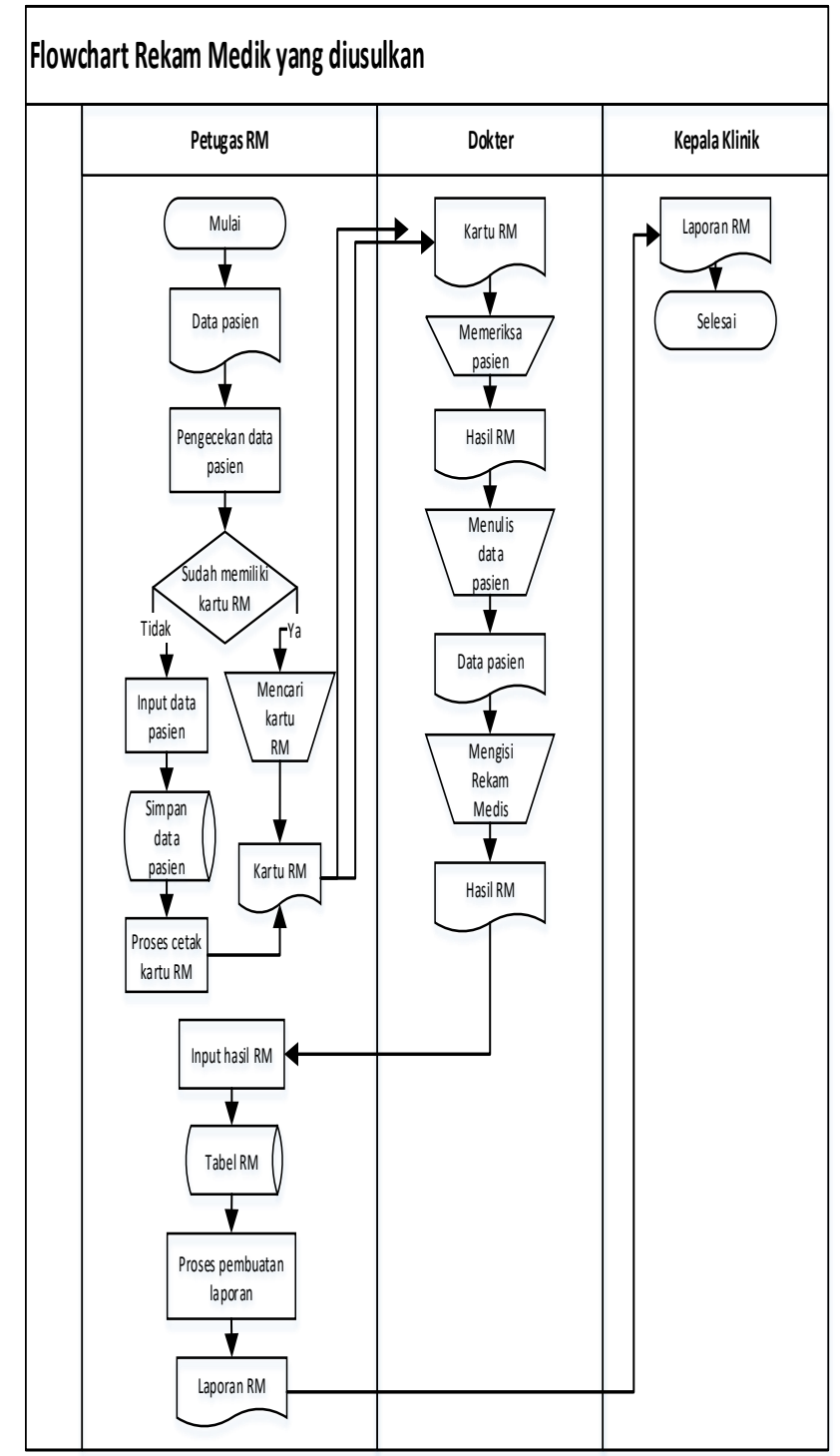

Fig. 2. Flowchart rekam medik yang diusulkan

\section{Rancangan Diagram Context}

Diagram context merupakan suatu diagram alir yang menggambarkan aliran sistem kerja yang ada. Rancangan diagram context rekam medis seperti yang ditunjukkan pada gambar 3 .

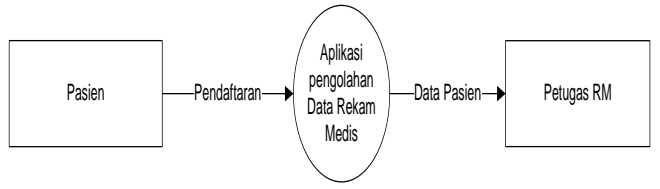




\section{Rancangan Data Flow Diagram (DFD)}

Data flow Diagram (DFD) merupakan arus data suatu sistem pengolahan data yang di gambarkan dalam bentuk diagram. Rancangan Data Flow Diagram (DFD) dibuat menjadi 3 level, untuk level 0 dapat dilihat pada gambar 4 dan level 1 dapat dilihat pada Gambar 5, dan level 2 dapat dilihat pada Gambar 6 dan 7.

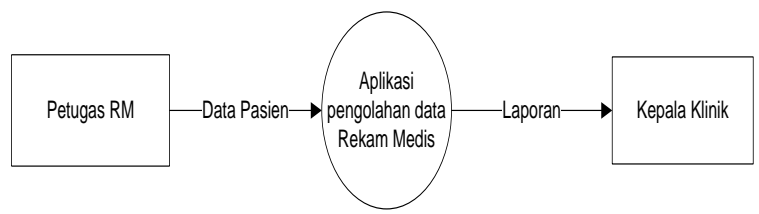

Fig. 4. Data Flow Diagram (DFD) level 0

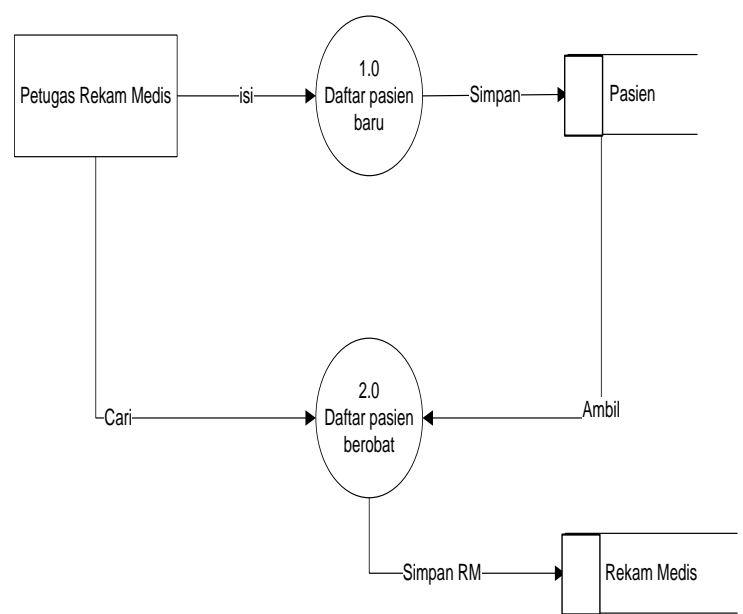

Fig. 5. Data Flow Diagram (DFD) level 1

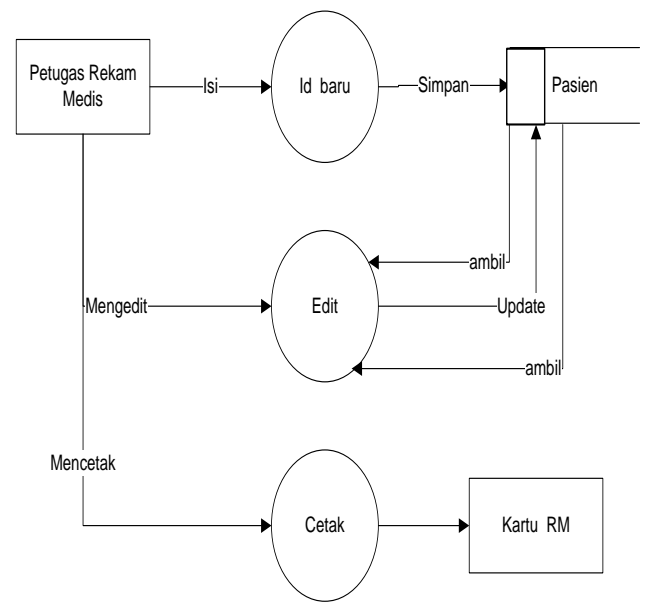

Fig. 6. Data Flow Diagram (DFD) level 2.1

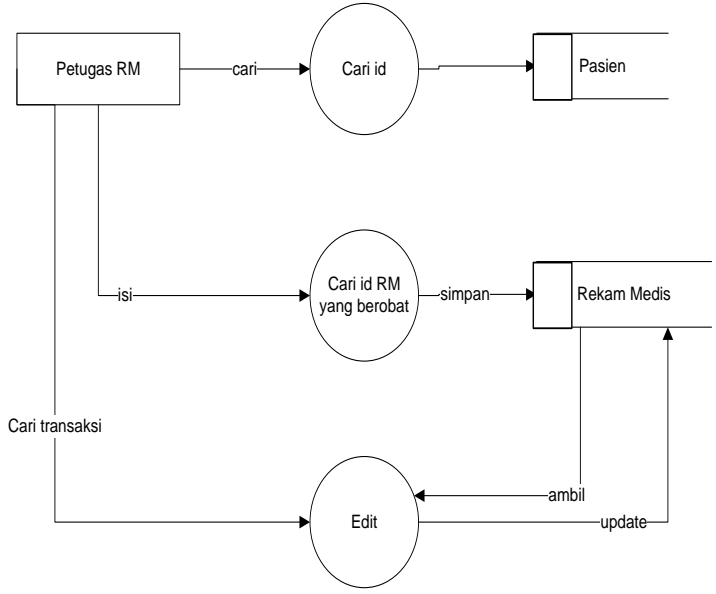

Fig. 7. Data Flow Diagram (DFD) level 2.2

3. Rancangan Entity Relationship Diagram (ERD)

Entity Relationship Diagram (ERD) suatu diagram untuk mengambarkan desain konseptual dari model konseptual suatu basis data relasional, dapat dilihat pada Gambar 8.

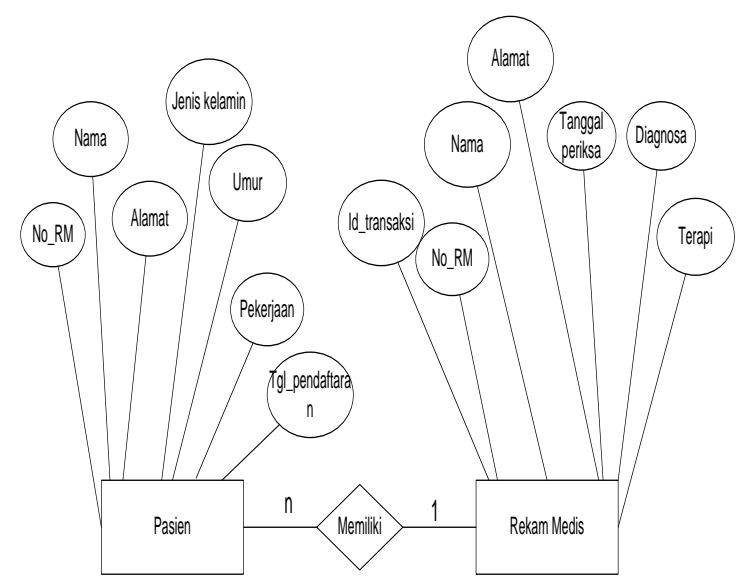

Fig. 8. Entity Relationship Diagram (ERD)

\section{J. Pengembangan Aplikasi}

Pengembangan aplikasi pengolahan data rekam medik pasien pada Klinik Hadi Wijaya menggunakan dukungan perangkat lunak dank eras yang dapat dilihat pada Tabel 3. 


\begin{tabular}{|c|c|}
\hline $\begin{array}{c}\text { Perangkat Lunak } \\
\text { (Software })\end{array}$ & $\begin{array}{c}\text { Perangkat Keras } \\
\text { (Hardware })\end{array}$ \\
\hline $\begin{array}{c}\text { Sistem Operasi Windows } \\
2007\end{array}$ & Processor Intel Inside \\
\cline { 1 - 1 } Borland Delphi 7.0 & Memory (RAM) 2 GB \\
\hline XAMMP & Hard Disk 550 GB \\
\hline Quick Report & \\
\hline ODBC &
\end{tabular}

Hasil yang diperoleh dari pengembangan sistem adalah sebuah prototipe aplikasi pengolahan data rekam medik pada Klinik Hadi Wijaya Kota Metro dengan rincian sebagai berikut.

\section{Tampilan Login}

Halaman ini berfungsi sebagai pintu untuk masuk ke system. Pengguna diharuskan memasukkan usernamedan password saat akan melakukan pemrosesan data pada aplikasi pengolahan data rekam medik seperti yang ditampilkan pada Gambar 9 dan akan menuju halaman utama setelah proses login berhasil dengan tampilan yang ditunjukkan pada Gambar 10.
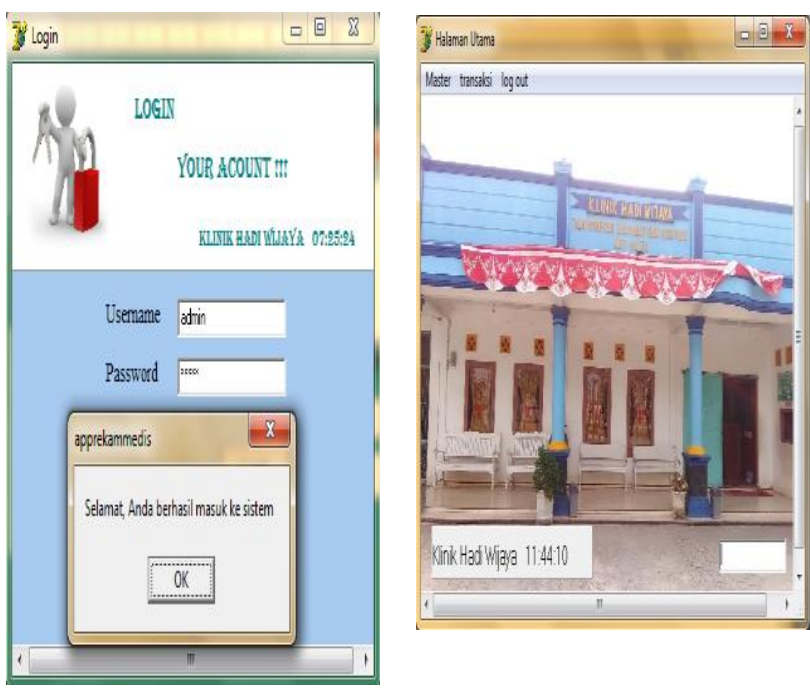

Fig. 9. Tampilan Halaman Login Utama memasukkan data rekam medik pasien yang sudah terdaftar seperti yang ditunjukkan pada Gambar 12 .

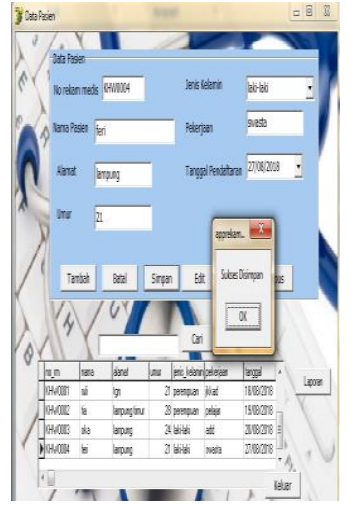

Fig. 11. Halaman input data pasien

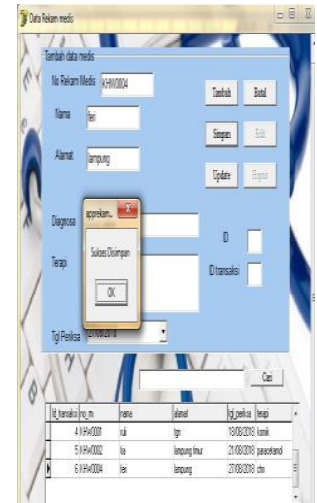

form Fig. 12. Halaman form input data rekam medik

\section{Form Laporan periodik}

Halaman ini berfungsi sebagai tempat untuk membuat laporan periodik sesuai dengan yang diperlukan seperti yang ditunjukkan pada Gambar 13 . Laporan tersebut didesain untuk dapat langsung dicetak sebagai laporan lengkap dengan kop surat, tanggal pembuatan laporan dan nama penanggung jawab untuk verifikasi data laporan tersebut. Gambar 14 menunjukkan contoh laporan data pasien dan data rekam medik yang dicetak dengan kurun waktu satu bulan.

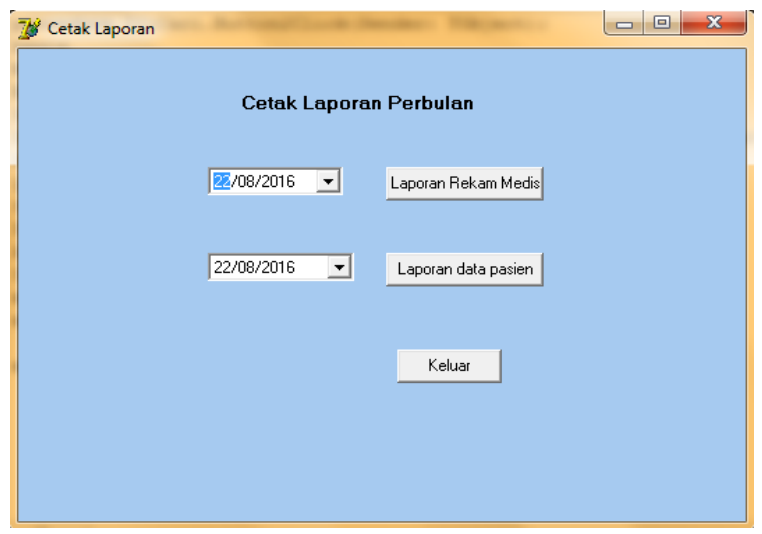

Fig. 13. Form Laporan Periodik

\section{Form input}

Ada dua halaman form input yang ada pada aplikasi ini, yaitu form input data pasien dan form input rekam medik. Halaman form input data pasien berfungsi sebagai form untuk memasukkan data pasien dengan no rekam medis yang sudah terotomatis dari sistem seperti yang ditunjukkan pada Gambar 11. Sedangkan halaman form input data rekam medik berfungsi sebagai form untuk 


\section{Jurnal IImu Komputer \& Iniormatika JIKI}

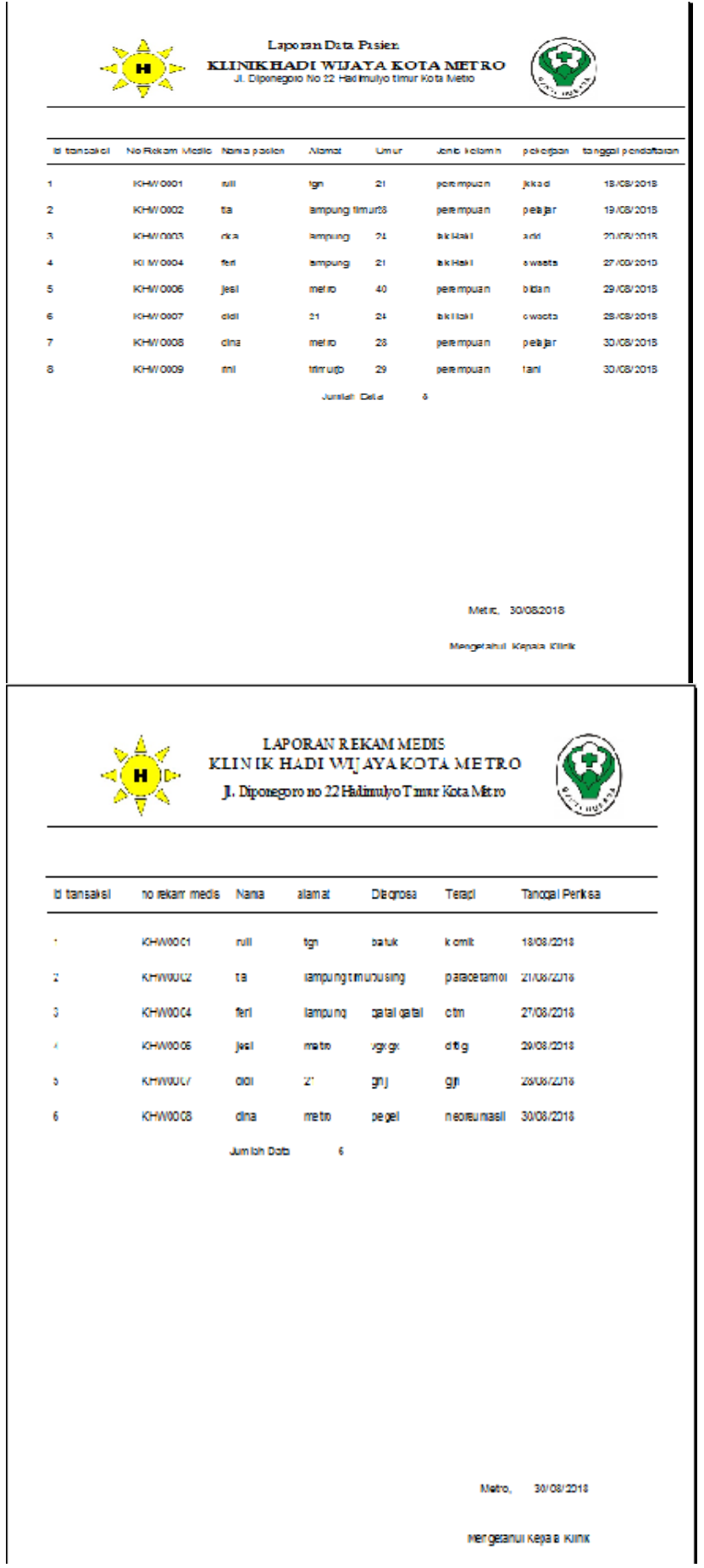

Fig. 14. Contoh Laporan bulanan data pasien dan data rekam medik

\section{K. Pengujian}

Setelah prototipe dirasa sudah cukup memenuhi requirement yang dibutuhkan, kemudian aplikasi tersebut dilakukan pengujian kepada pihak Klinik Hadi Wijaya Kota Metro. Pengujian dilakukan oleh beberapa pihak yang ada di Klinik tersebut. Umpan balik yang didapat dari proses ini peneliti rangkum dalam bentuk kelebihan dan kekurangan dari sistem ini, seperti berikut.

1. Kelebihan dari sistem informasi geografis siswa

- Dengan menggunakan aplikasi pengolahan data rekam medis pasien menggunakan borland delphi 7.0 dapat mempermudah pencarian data rekam medis pasien.

- Mempermudah pembuatan laporan rekam medis pasien

2. Kekurangan Program

- Program aplikasi ini berbasis Desktop belum berbasis online.

- Program aplikasi ini masih berdiri sendiri belum berbasis clien server.

- Tampilan aplikasi yang masih sederhana.

\section{KESIMPULAN}

Berdasarkan hasil penelitian yang telah dilakukan pada Klinik Hadi Wijaya Kota metro, dapat disimpulkan bahwa berdasarkan hasil pengembangan dan pengujian yang telah dilakukan, Aplikasi Pengelolaan Data Rekam Medik untuk Klinik Hadi Wijaya Kota Metro telah berhasil dikembangkan. Aplikasi ini telah berhasil memenuhi kebutuhan awal dari proses pengelolaan rekam medik yang ada di klinik tersebut. Selain itu, aplikasi ini juga sudah bisa dikatakan berhasil untuk menggantikan proses pengelolaan data rekam medik yang masih dilakukan secara manual.

Hasil pengujian aplikasi ini menunjukkan bahwa pihak Klinik Hadi Wijaya Kota Metro menggaris bawahi terkait infrastruktur aplikasi yang belum berbasis client server dan pengembanga aplikasi yang berbasis desktop. Hal ini dapat digunakan untuk pertimbangan penelitian selanjutnya terkait pengembangan aplikasi pengelolaan data rekam medik untuk Klinik Hadi Wijaya Kota Metro.

Pengimplementasian Aplikasi Pengelolaan Data Rekam Medik untuk Klinik Hadi Wijaya Kota Metro dapat lebih mempermudah pihak klinik dalam kegiatan operasional pengelolaan data rekam medik. Aplikasi ini juga sangat mempermudah pihak administrasi dalam pembuatan laporan terkait data rekam medik maupun data pasien yang dapat dicetak sesuai dengan jangka waktu yang dibutuhkan. Hal ini akan sangat membantu dalam pengelolaan waktu administrasi dalam proses pengelolaan data rekam medik tersebut.

\section{DAFTar Pustaka}

D. Iflahah, I. Aknuranda, and N. Y. Setiawan, "Analisis dan Perancangan Sistem Informasi Rekam Medis Poli Gigi (Studi Kasus : Puskesmas Sumbersari Kecamatan 


\section{Jurnal IImu Komputer \& Iniormatika JKI}

Saradan Kabupaten Madiun)," J. Pengemb.

Teknol. Inf. dan Ilmu Komput. Univ.

Brawijaya, vol. 2, no. 6, pp. 2121-2130,

2018.

[2] D. Avison and G. Fitzgerald, Information systems development: methodologies, techniques and tools (4th edition). New York: McGraw-Hill Education, 2006.

[3] D. Avison and G. Fitzgerald, Information Systems Development Advances in Methodologies, Components, and Management, 1st ed. 2002.

[3] N. Nuraini, “Analisis Sistem Penyelenggaraan Rekam Medis di Instalasi Rekam Medis RS ' $\mathrm{X}$ ' Tangerang Periode April-Mei 2015," Arsi, vol. 1, pp. 147-158, 2015.

[4] Menteri Kesehatan, "Permnekes RI Nomor 749a Tahun 1989," 1989.

[5] Permenkes, "Peraturan Menteri Kesehatan Republik Indonesia No. 46 Tahun 2017,” no. December, 2017.

[6] Permenkes, "Peraturan Menteri Kesehatan Republik Indonesia No. 269 Tahun 2008," Peraturan Menteri Kesehatan Republik Indonesia. 2008.

[7] R. S. Pressman, Software Engineering A Practitioner's Approach 7th Edition. 2010.

[8] Saputra, D. D., \& Sudarmaji, S. (2017). Pemodelan Sistem Aplikasi Pengolahan Data Pasien Pada Rumah Sakit Islam Kota Metro Lampung. Mikrotik: Jurnal Manajemen Informatika, 7(1). 